\title{
SUSTAINABLE RECYCLING OF HOTEL WASTE WATER IN GOA
}

KEY WORDS: Grey water, MBR, EM, Recycling.

\section{Dr. Dilecta D'Costa*}

\section{Mahesh Bakal}

HOD of Department of Microbiology, Government college of Arts, Science and Commerce, Khandola, Marcela-Goa, India. *Corresponding Author

\author{
Dr. Anvekar Envirocare and Research lab, Mapusa, Goa, India.
}

Professor at St. Xavier's College, Mapusa, Goa, India.

Goa, a tourist destination known for its alarming scenic beauty has seen a consistently rising trend in hotel occupancy for star category hotels. On an average a luxury hotel would consume approximately 200,000 litres of water per day. The waste water generated from this consumption is basically $30 \%$ of black water (sewage) and $70 \%$ of grey water (bath water, laundry waste water, etc). A study was carried out to harness the potential of grey water before dumping into water bodies per se. A membrane based bio reactor (MBR) designed for chemical and biological treatment of this waste water includes mechanisms like coagulation, flocculation \& separation of the water ludge. The water is then validated for its BOD \& COD levels as per the government norms and then membrane filtered to remove total dissolved solids (TDS). This filtered water is then subjected to biological treatment whereas the sludge is used in landfills. EM technology uses commercially available culture of microorganisms, comprising of Lactobacillus, photosynthetic bacteria and yeast for biological treatment of the waste water to render it safe for human use. Monitoring and water quality analysis revealed that microbial treatment considerably reduced the BOD. This innovative technology allows the recycling of waste water which can be made use of for different purposes like gardening, cleaning floors \& hotel properties, washing of cars \& flushing. Moreover, it requires low foot print and involves easy installation and less maintenance. Recycling of grey water would in turn curtail consumption, thus cutting cost for purchase of water and ensuring safety of consumers. In addition to MBR \& EM Technology being economically feasible, safe and user-friendly, its usage is highly recommended to maintain a stable water table and preserve the integrity of the hospitality industry in Goa. It is surely an initiative to minimize water crisis thus maintaining a sustainable ecosystem.

\section{INTRODUCTION}

Water is one of the most precious resources of this planet and is vital for sustainable development. Only $2.5 \%$ of all water is fresh water which makes it a limited resource to support an over expanding population.(Sodhi, I., 2018). More than one in three people globally do not have access to safe drinking water and more than 4 billion people lack adequate sanitation. A report from the United Nations has estimated that in the year 2025, 2.7 billion people will be facing water shortage problems.( Juan, Y.et al., 2016). Hence a concrete challenge is to meet the UN target that aims at providing safe drinking water and hygienic sanitation to all the people on this earth by 2025. ( van der Vleuten-Balkema, A., 2003). It is true that the water scarcity we are witnessing today is because of climate change but there is also a lack of water management by humans. The International Water Management Institute has projected that the total global urban water consumption will increase from 1995 to 2025 by $62 \%$.(Zadeh, S. et al., 2013). Hence there is a need for nations to align water perspectives to allow peaceful and effective integrated water resource management and sustainable use. Effective management will mean tackling neglected issues such as water wastage in current systems, which has been estimated to be up to $30 \%$. Thus waste water has to be used more efficiently.

One of the most important milestones has been the recognition of the human right to water and sanitation by the United Nations General Assembly in July 2010.80 per cent of wastewater flows back into the ecosystem without being treated or reused. (UNESCO, 2017). The United Nations recognizes the importance of addressing the global water crisis each year on World Water Day, March 22. The International Decade for Action, 'Water for Sustainable Development,' started on World Water Day, $22^{\text {nd }}$ March, 2018 and will end on World Water Day, $22^{\text {nd }}$ March, 2028. This decade is about accelerating efforts through Sustainable Development Goals (SDGs) towards meeting water-related challenges, including limited access to safe water and sanitation, increasing pressure on water resources and ecosystems, and an exacerbated risk of droughts and floods. Limited water supplies would call for recovery and reuse of limited resources. Treatment of industrial effluents in multipurpose water schemes and use of wastewater (grey water) would endorse successful planning of waste water recycling. Grey water is wastewater originating from showers, baths, bathroom sinks, kitchen sinks and laundries. It does not include toilet or garbage wastes, or wastewater contaminated by soiled diapers. (Fig. 1)

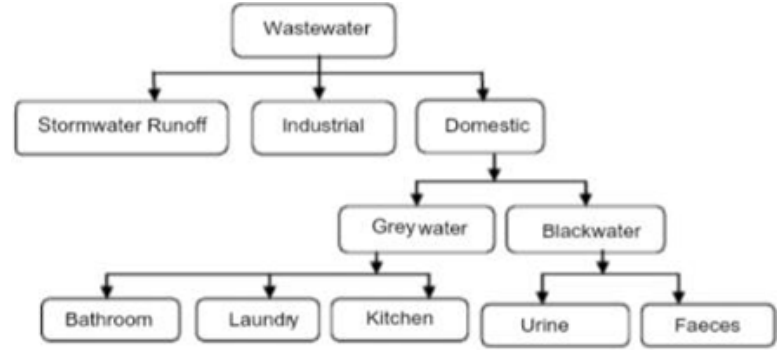

Fig. 1 Types OfWasteWater (Amoatey, P.et al.,2011)

Despite the fact that it may include a complex mixture of organic matter, suspended solids, bacteria and common household chemicals, if treated properly, it can help preserve limited water supplies.( Shamabadia, N. et al., 2015). The reuse of grey water is a potential solution for water deprived regions worldwide. (Oteng-Peprah, M. et al., 2018). Its use for non-potable applications, such as toilet flushing or irrigation, can substantially reduce potable water consumption. (Winward, G.et al., 2008, a).

Grey water can be considered as a suitable candidate for reuse as it is consistently produced and is readily available onsite for reuse. (Winward, G.et al., 2008, b). In addition, if this grey water is not treated and dumped into river bodies, it would lead to water and land pollution and increase health hazards. Thus it becomes extremely necessary to have a 
proper waste/grey water management system.(Naik, K. et al., 2016).

India is the largest user of freshwater in the world even though it has only $4 \%$ of the world's water supply and has to feed $17 \%$ of the world's population.(Sodhi, I., 2018). According to a UN report, India's population is outgrowing its water supply. Demand for water will reach twice the available supply by 2030, placing hundreds of millions of lives in danger. According to this database compiled by the World Resources Institute, (USA), India ranks 13 among the 17 worst affected countries. The focus of the Ministry of Jal Shakti, Government of India which has been recently constituted is to enable effective water management in Indian states in the face of a growing water crisis in India.

The World Health Organization (WHO) states that an individual requires approximately 25 litres of water daily for meeting his/her basic hygiene and food needs. The rest is used for non-potable purposes like mopping and cleaning. This indicates that for most of the non-potable uses, a quality lower than drinking water is required. Thus, for economic efficiency and environmental sustainability, water must be treated and supplied according to usage. Reports of waste waters polluting water bodies are rampant, so much to say that the once upon a time pristine and serene rivers have lost their biodiversity and become dump yards. A study carried out highlights the water quality issues in 275 rivers comprising of 302 Stretches in 27 States and 2UTs. Increase in Biochemical Oxygen Demand (BOD) indicating organic pollution continues to be the major water quality issue. This is mainly due to the discharge of untreated domestic wastewater from the urban areas of the country.( CPCB, 2015).

There is a huge potential in reusing this treated wastewater /grey water at least for non-potable purposes, which is cost effective. Recycled wastewater also helps to reduce scarcity and ease pressures on groundwater and other natural water bodies. A decentralised approach, with a key focus on water conservation, source sustainability, storage and reuse wherever possible needs to be promoted. The hospitality industry has the dual challenge of not only ensuring customer satisfaction but also attempt to reduce water usage and its wastage. Water is essential for the proper functioning of a hotel, which requires heavy quantities for guest comfort, hygiene, and food preparation. Tourists have been known to consume 16 times more water than locals on an average. Such excess water usage by tourists can lead to conflicts of hotels with the locals who would face extreme water shortages. As hotels consume huge quantities of water regularly, it has become imperative for them to increase water conservation efforts. Sustainable water/ wastewater management at tourist resorts should incorporate measures such as:- (1) All treated wastewater should be reused (2) Reuse is recommended for all non-potable purposes.(Kavanagh, L. 1999)

Goa is the most replenishing dream destination for a large number of tourists. The adorable beaches lining its coast line is home to the most exotic hotels flourishing the tourism industry in Goa. On an average, if there is $80 \%$ occupancy, then a luxury hotel would consume approximately 200,000 litres of water per day. The waste water generated from this consumption is basically $30 \%$ of black water (sewage) and $70 \%$ of grey water (bath water, laundry waste water, etc). Grey water can be defined as any domestic wastewater produced, excluding sewage. The main difference between grey water and sewage (or black water) is the organic loading. Sewage has a much larger organic loading compared to grey water. Black water is allowed to be treated by the sewage treatment plant but the majority of waste water i.e the grey water could be recycled thus employing judicious use of waste water. An ever increasing demand of water to cater to the rise in the number of hotels in Goa would result in a huge amount being spent on purchasing water. To alleviate this problem, a study was carried out to harness the potential of grey water before dumping into water bodies as such.

\section{Objectives}

1.To recycle grey water generated from star hotels in Goa for reuse in gardening, toilet flushing, hotel property cleaning and car washing.

2. To facilitate waste water management at a low cost, limited space and less manpower.

3. To reduce the purchase of water from water tankers.

4. To maintain sustainability of the water table by decreasing nutrient concentration in the environment.

\section{Methodology}

The study was carried out on 9 hotels across North and South Goa. Recycling of grey water was carried out as per the flow chart (Fig. 2)

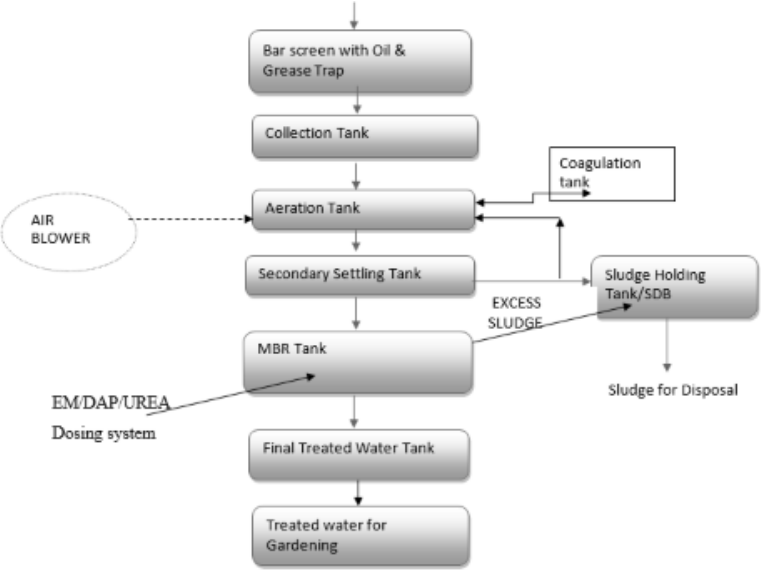

Fig. 2 Process Flow Chart

Grey water from these hotels was collected on site into collection tanks made of either RCC MS-FRP (Reinforced Cement Concrete Mild Steel Fire Reinforced Plastic) or RCC MSEP (Reinforced Cement Concrete Mild Steel Epoxy painted) possessing a capacity of $1 \mathrm{KLD}$ (Kilo litres per day) to 10 MLD (Million litres per day). This was allowed to flow into an equalizer tank to which ferric alum and bleaching powder was added in a proportion of $10 \mathrm{~kg}$ per $100 \mathrm{KLD}$ of grey water. Initially $10 \mathrm{~kg}$ of ferric alum is mixed with $1000 \mathrm{lts}$ of water and bleaching powder is also treated the same way but with constant stirring to ensure uniform solution. The two solutions are dosed into the grey water in a continuous process with a retention time of 30 to 60 minutes. This process leads to coagulation after which the water is passed through a tube settler.

The tube settler separates the sludge from the water which is used in landfills. The water is then directed to a MBR (Membrane-based Bio Reactor) tank. The membrane employed is a Cubical skid of either a sulphate based membrane or ceramic based membrane of dimension 0.6 meter $\times 0.9$ meter $x$ height 1.2 meter. having a pore size of 0.06 microns. The life of the membrane is around 3-5 years. Simultaneously, a tank containing EM (Effective Microorganisms) which is commercially available (Maple EM.1 - Effluclean) is allowed to mix with the partially treated water for 24 hours before it is filtered through the membrane. The EM solution is formulated as follows:- (1lt EM $+1 \mathrm{~kg}$ jaggery +200 lt of cooked rice water solution). The flow rate of EM entering the MBR is $8.3 \mathrm{lts} / \mathrm{h}$. This step is important to decrease the BOD. The last step comprises of the filtered and treated water which has TDS $<500$, flowing into the treated water tank which can be safely used for non potable purposes. Aliquots in triplicates of the treated water were analysed for various parameters viz. pH, NH4-N, TSS, COD, BOD, Total hardness and Fecal coliforms as per APHA $23^{\text {rd }}$ edition. 


\section{RESULTS \& DISCUSSION}

A study, concerning grey water management practice of 09 hotels in Goa was recently undertaken and the potential for combining treatment with reuse was utilised. The results of one of the samples showed that the COD and BOD values before treatment are $152 \mathrm{mg} / 1$ and $36.48 \mathrm{mg} / \mathrm{lt}$. and after treatment are less than $4.0 \mathrm{mg} / \mathrm{lt}$ and less than $2.0 \mathrm{mg} / \mathrm{lt}$ respectively. (Tables $1 \& 2$ )

\section{Table 1: Analysis Before Treatment}

\begin{tabular}{|c|c|c|c|c|c|c|}
\hline \multicolumn{2}{|c|}{ Sample detals } & \multicolumn{2}{|c|}{ Laundry Water } & \multicolumn{2}{|c|}{ Date af Colloction } & $26 / 1 / 18$ \\
\hline \multicolumn{2}{|c|}{ Sample Colhocted by } & \multicolumn{2}{|l|}{ Clent } & \multicolumn{2}{|c|}{ Sample Rleceived On } & $26 / 1 / 18$ \\
\hline \multicolumn{2}{|c|}{ Ansysis Stanted On } & \multicolumn{2}{|l|}{ 2611าง } & \multicolumn{2}{|c|}{ Anatyis Compietod On } & $01 / 72 / 18$ \\
\hline \multicolumn{2}{|c|}{ Sanple Continet } & \multicolumn{2}{|c|}{ Glans bottie + PVC Can } & \multirow{2}{*}{\multicolumn{2}{|c|}{ Sample Ouantly }} & $1000 \mathrm{mit}+2000 \mathrm{mi}$ \\
\hline \multicolumn{6}{|c|}{ Chemical Parameters } & \\
\hline Sr.Na & \multicolumn{2}{|c|}{ Parameters } & Results & Unit & \multicolumn{2}{|c|}{ Wethod } \\
\hline 1. & \multicolumn{2}{|l|}{ pH } & 6.86 & 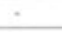 & \multicolumn{2}{|c|}{ APHW(25Etedion) $4500 \mathrm{H}+\mathrm{B}$} \\
\hline 2. & \multicolumn{2}{|l|}{ Turbidty } & 6.2 & NTU & \multicolumn{2}{|c|}{ APPW(23Etedion) 2130B } \\
\hline 3. & \multicolumn{2}{|c|}{$\begin{array}{l}\text { Cherical Oxygen Demand } \\
\text { (COO) }\end{array}$} & 15200 & mgle & \multicolumn{2}{|c|}{ APHA( 23 Edtion) $5220-8$} \\
\hline 4. & \multicolumn{2}{|c|}{$\begin{array}{l}\text { Biochemical Oxygen } \\
\text { Demand }(2 \pi \times 3 \text { Con) }(800)\end{array}$} & 36.48 & molt & \multicolumn{2}{|c|}{ 15 3025 (Part 44$)$} \\
\hline 5. & \multicolumn{2}{|c|}{$\begin{array}{l}\text { Total Susperdod Solds } \\
\text { (TSS) }\end{array}$} & 23.00 & molt & \multicolumn{2}{|c|}{ APHW( 23-Edition) 2540-D } \\
\hline 6. & \multicolumn{2}{|c|}{ Total Dissolved Solids } & 437.00 & molit & \multicolumn{2}{|c|}{ APHA( 23VEdrion) $2540 \mathrm{C}$} \\
\hline 7. & \multicolumn{2}{|c|}{ Total Hardness as $\mathrm{CaCO}$, } & 50.00 & molit & \multicolumn{2}{|c|}{ APHA( 230Edtion) $2340 \mathrm{C}$} \\
\hline
\end{tabular}

\section{Table 2: Analysis After Treatment}

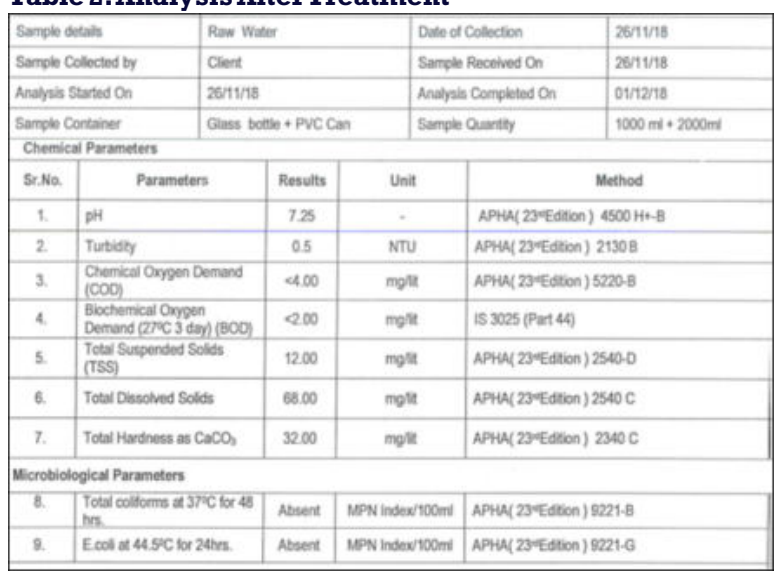

Average values of all the samples showed an appreciable decrease. It is evident that organic matter reduction was achieved successfully as the values obtained are within permissible limits of the regulatory norms as per Govt. Of India CPCB notification.(Table 3)

\section{Table 3: Effluent Discharge Standards For STP}

Effluent discharged standards for Sewage Treatment Plant are mentioned below:

\begin{tabular}{|c|c|c|c|}
\hline $\begin{array}{l}\text { SI. } \\
\text { No. }\end{array}$ & Industry & Parameters & $\begin{array}{c}\text { Standards for New STPs (Design after } \\
\text { notification date) }\end{array}$ \\
\hline & \multirow{7}{*}{$\begin{array}{l}\text { Sewage } \\
\text { Treatment Plant }\end{array}$} & $\mathrm{pH}$ & $6.5-9.0$ \\
\hline & & BOD & 10 \\
\hline & & COD & 50 \\
\hline & & TSS & 20 \\
\hline & & $\mathrm{NH}_{4}-\mathrm{N}$ & 5 \\
\hline & & $\mathrm{N}$-total & 10 \\
\hline & & $\begin{array}{l}\text { Fecal Coliform } \\
\text { (MPN/100ml) }\end{array}$ & $<100$ \\
\hline Note: & \multicolumn{3}{|c|}{$\begin{array}{l}\text { (i) All values in } \mathrm{mg} / \mathrm{except} \text { for } \mathrm{pH} \text { and Coliform. } \\
\text { (ii) These standards will be applicable for discharge in water resources as well as } \\
\text { for land disposal. The standards for Fecal Coliform may not be applied for use }\end{array}$} \\
\hline & \multicolumn{3}{|c|}{$\begin{array}{l}\text { of treated sewage in industrial purposes. } \\
\text { * Achievements of Standards for existing }\end{array}$} \\
\hline
\end{tabular}

Reduction in COD takes place at the level of the equalizer tank whereas reduction in $B O D$ at the second last stage i.e. the MBR + EM stage

A report on decentralized grey water recycling system for 223 inhabitants in

Berlin, Germany showed that high load grey water undergoes advanced treatment in a multistage moving bed biofilm reactor (MBBR) followed by sand filtration and UV disinfection and the treated water is used safely as service water for toilet flushing.( Saidi, A.et al., 2017). Previous studies have suggested that biological processes should be preferred due to the high levels of organics in the water.(Winward, G.et al., 2008 a).

In our model the use of EM takes care of this and reduces the BOD to a level as prescribed by the government norms.

Grey water reuse is a promising alternative water source in view of the freshwater supply becoming increasingly scarce in addition to the high cost involved in the procurement of freshwater. In comparison to wastewater generated by industries or municipal treatment plants, grey water has been found to be more optimum for reuse applications, such as groundwater recharge, vehicle wash, fire extinguisher, toilet flushing etc.,(Albalawneh, A. et al.,2015)

In countries with limited water resources, reclaimed water may contribute considerably to the water budget and alleviate stress on fresh water resources. (Halalsheh, M. et al., 2008)

Grey water has a lower organic pollutant and pathogen content as compared to combined municipal wastewater which also contains black water. Thus, grey water is considered particularly suitable for on-site treatment and reuse. (Revitt,D.et al.,2011).

This system requires little space and maintenance work of less than one hour per month and it shows operational stability under peak loads. Moreover it is a decentralized system as compared to a centralized system which is inflexible and an expensive investment. Eco-resort developments fall easily into the category of sites where decentralised wastewater treatment systems are most beneficial. (Kavanagh, L. 1999)

With regard to cost effectiveness, MBR is a model of choice. Ferric alum and bleaching powder which is used in the equalizer tank costs Rs. $20 / \mathrm{kg}$ and Rs. $30 / \mathrm{kg}$ respectively as compared to Polyelectrolyte which was used initially at the rate of $\mathrm{Rs} .280 / \mathrm{kg}$. The present study has revealed that the efficiency of this process in all the nine hotels is commendable and the cost of purchasing water for hotel use has drastically reduced. Though commercially available EM was used for the treatment of grey water, a mixture of rice water, jaggery and curd together with the consortium of relevant bacteria and yeast can be used instead. This would surely cut down costs dramatically. This study is underway and more research needs to be done. Besides, this technology has low foot print, can be retrofit in existing technology and it can increase capacity of existing plants by almost $30 \%$.

\section{Benefits of MBR-L-WTP are as follows}

01 . Completely automatic plant, with plc based automation.

02. Low footprint

03. Less maintenance.

04.Better treated water quality. (Fulfils existing latest norms).

05. Water re-use for gardening, flushing, \& floor washing.

06. Easy \& faster installation.

07. Decentralised system

In conclusion, the study has proved its efficacy for successful treatment of grey water making it useful for non potable uses in the hotel industry. Since recycling and reuse is crucial for sustainability, the objectives of this study have been fulfilled thus lowering the burden of water crisis. There is a French poem from Jean de La Fontaine about a grasshopper and an 
ant. The grasshopper just spends his time in the summer enjoying life but the ant keeps working hard throughout the summer to save all of his supplies for the winter. In this way, we need to be like the ant, preparing water supplies for today and for tomorrow.

\section{REFERENCES}

1) Albalawneh , A., \& Chang, T.(2015) Review of the greywater and proposed greywater recycling scheme for agricultural irrigation reuses Int. Journal of Research - Granthaalayah 3(12): 16-35.

2) Amoatey, P., \& Bani,R.(2011)Wastewater Management www.intechopen.com $389-398$.

3) CPCB Envis Newsletter on Control of Pollution (2015) www.cpcbenvis.nic.in $1-7$.

4) Halalsheh, M..Dalahmeh, S., Sayed, M. Suleiman, W., Shareef, M., Mansour, M., \& Safi, M. (2008) Grey water characteristics and treatment options for rural areas in Jordan Bioresource Technology 99: 6635-6641.

5) Juan, Y., Chen Y., \& Lin, J. (2016) Grey water Reuse System Design and Economic Analysis for Residential Buildings in Taiwan. Water. 8:546.

6) Kavanagh, L. J. (1999) Water management and sustainability at Queensland tourist resorts. Thesis submitted to The University of Queensland: 1 -15

7) Naik, K., Shah, R., \& Jain, P. (2016) Analysis, Reuse and Recycling of GreyWater. Global Research and Development Journal for Engineering 023:128-133.

8) Oteng-Peprah, M., Acheampong, M. A., \& deVries, N. K. (2018) Grey water Characteristics, Treatment Systems, Reuse Strategies and User Perception-a ReviewWater Air Soil Pollut. 229:255.

9) Revitt, D. M., Eriksson, E., \& Donner, E.(2011) The implications of household grey water treatment and reuse for municipal wastewater flows and micropollutantloads. Water Res 45(4):1549-60.

10) Saidi, A., Masmoudi, K., Nolde, E., El Amrani B.,\& Amraoui, F.(2017). Organic matter degradation in a greywater recycling system using a multistage moving bed biofilm reactor(MBBR) Water Sci Technol. 76 (11-12):3328-3339.

11) Shamabadia, N., Bakhtiari, H., Kochakianc, N., \& Farahanib, M. (2015). The investigation and designing of an onsite grey water treatment systems at Hazrat-e-Masoumeh University, Oom, IRAN Energy Procedia 74: 1337 - 1346

12) Sodhi, I.S., (2018) Water Management in India. In Chandra, S. (ed) Socrates (pp. 129) Socrates Scholarly Research Journal.

13) van der Vleuten-Balkema, A.J. (2003) Sustainable Wastewater Treatment : developing a methodology and selecting promising systems. Thesis submitted to Technische Univesiteit Eindhoven 1-73.

14) Winward, G. P., Avery, L. M., Stephenson, T., \& Jefferson, B. (2008 b). Chlorine disinfection of grey water for reuse: Effect of organics and particles. Water Research $42: 483-491$.

15) Winward, G. P., Avery, L.M., Frazer-Williams, R., Pidou, M., Jeffrey, P., Stephenson, T., \& Jefferson, B. (2008 a). A study of the microbial quality of grey water and an evaluation of treatment technologies for reuse. Ecological engineering $32: 187-197$.

16) Zadeh, S. M., Hunt , D. V.L., Lombardi, D. R., \& Rogers, C. D.F. (2013) Shared Urban Grey water Recycling Systems:Water Resource Savings and Economic Investment. Sustainability 5:2887-2912. 